\title{
Reflecting on Contemporary Administration
}

\author{
Refletindo sobre Administração Contemporânea
}

Marcelo de Souza Bispo*1,2

\section{PREAMBLE}

In my first editorial of Journal of Contemporary Administration (RAC), I would like to start by expressing my joy and drive to continue the scientific and editorial work of this nearly 25 -year-old journal. I am grateful both to the current ANPAD board (2021-2024) for their trust in me and to all editors that preceded me (Clóvis Luiz Machado-daSilva, César Gonçalves Neto, Tomas de Aquino Guimarães, Rogério Hermida Quintella, Herbert Kimura, and Wesley Mendes-da-Silva) for their contributions to leading $R A C$ to its current level of excellence. I hope to measure up (along with the entire editorial team) and I will do all my best to keep $R A C$ as a national reference and contribute to its international prestige in the field of administration. I am quite aware of the responsibilities and challenges ahead.

Besides these initial acknowledgments, I would like to present some reflections on the notion of 'contemporary administration'. This initiative is part of a demand from the current ANPAD board to define clearer focuses and scopes for the Association's journals, RAC and BAR - Brazilian Administration Review, with the help of a working group formed by people with extensive scientific and editorial experience. In coming up with a focus and scope that

\footnotetext{
* Corresponding Author.

1. Universidade Federal da Paraiba, Programa de Pós-Graduação em Administração, João Pessoa, PB, Brazil. 2. Editor-in-chief of the Journal of Contemporary Administration (RAC).
}

distinguish $R A C$ from $B A R$, the working group and current associate editors at $R A C$ have defined that the idea of 'contemporary' is the best way to justify the journal's name and honor its trajectory over nearly 2.5 decades. However, while the word 'contemporary' seems to be adequate for thinking about administration and is supposedly known by our entire audience, presenting an adequate understanding of it is complex, yet necessary.

I provide two assumptions that should help in the development of the ideas that follow. The first assumption is that 'contemporary' does not refer to the simple dictionary definition of something that belongs to the present time or two or more things that belong to the same period of time. The second assumption concerns the range of contemporary possibilities: while it is possible to think of research in all fields contemporarily, not everything fits within the scope of $R A C$. Bearing these two assumptions in mind, I will provide a reflection on what we can think of as 'contemporary'. The aim is to reflect on the notion of 'contemporary administration' that $R A C$ intends to debate with the academia in particular and with the society in general. 


\section{ON THE NOTION OF WHAT IS CONTEMPORARY}

The understanding that the adjective 'contemporary' refers to the present time is very common in several contexts, including in the academia. The use of this word is recurrent, with its meaning usually taken for granted. My idea here is not to monopolize the general understanding and usage of the word 'contemporary', but rather to provide an insight into it that is in line with the focus and scope of $R A C$. As such, 'contemporary' has to do with one's ability to apprehend their own time while both approaching it and distancing themselves from it (Agamben, 2009). Those who are very attached to the contemporary cannot interpret it, precisely because they lack the ability to detach themselves from it, that is, to feel uneasy about it and then get to know it and reflect on it. The contemporary is always the result of a historical process that helps us gain (new) knowledge of the present. "What makes us contemporary, then, is not the temporal condition of the present, but rather the currentness of an issue that involves us as actors of practices paradoxically inscribed in our tissues" (Pacheco, 2010 , p. 88). The contemporary is not tied exclusively to the present time; it has to do with an "identification regime" that allows us to perceive relevant themes for the current world (Rancière, 2005, p. 28). The contemporary brings in itself a "set of issues that remain relevant for a better understanding of people and the social, aesthetic and political context in which they act, create, think and transform" (Almeida, 2012, p. 73).

\section{CONTEMPORARY ADMINISTRATION}

Thinking about the contemporary within administration goes beyond a chronology of the present. Contemporary administration must seek to recognize in the present day a historical construction that both interweaves past, present and future and makes it possible to understand current ways of acting and organizing society. At the same time, contemporary administration must also be able to recognize, reflect and act on issues that are relevant in today's world. Therefore, it is not limited to what happens in the present, nor should it be detached from its social context. In fact, it cannot be reduced to an individualistic and supposedly 'rational' practice (Cabantous \& Gond, 2011) that presents itself as neutral, apolitical, and unproblematic (Alvesson \& Willmott, 1992). Neither can it be exclusively oriented towards maximizing the financial profits and well-being of a minority (Pio \& Waddock, 2021). Contemporary administration needs to engage in how to promote a more balanced relationship between the business world and society (Fleming \& Oswick, 2014; Rhodes \& Fleming, 2020; Zanoni, Contu, Healy, \& Mir, 2017).
A good initiative for thinking about the contemporary was the establishment of the Sustainable Development Goals of the United Nations (UN), which contain contemporary challenges that the global society faces and needs to mitigate. For instance, issues related to poverty and inequality, environment, quality education, decent work, responsible consumption, clean energy, peace and justice cannot be ignored when we do research in contemporary administration. Debates about the relationship between theory and practice (Bispo, 2021; Lundberg, 2004; Van de Ven, 1989), as well as the impact of research (Edwards \& Meagher, 2020; Godin \& Doré, 2005; Gunn \& Mintrom, 2017; Sandes-Guimarães \& Hourneaux, 2020), are meaningless if they are not coherently aligned with relevant contemporary themes.

Much of the problem in the supposed dichotomy between 'theory and practice' (Lundberg, 2004; Van de Ven, 1989) within administration (Bispo, 2021) resides precisely in the fact that several scholars in the field ignore social problems. As a result, several concepts and models have disregarded the social context and the actual motives and interests of various dominant discourses (especially in the business area). They either distort the reality or 'create' one that is sold as a common good while meeting only specific interests (Dardot \& Laval, 2013; Rhodes \& Fleming, 2020; Zanoni et al., 2017). ). If what we do departs from ideas that neglect the concrete, lived world, how can we possibly bring theory and practice closer together? We in administration tend to have a certain arrogance when we think that we know how things should be or work and eventually create models that seek to box reality in (Ghoshal, 2005). As a result, this logic transforms a symbiotic relationship into a dichotomous one when it comes to 'theory and practice'.

Something similar also applies to research 'impact'. Interestingly, we academically assume that impact is good! In not challenging this notion, we neglect the fact that no impact is unidirectional (Bispo \& Davel, in press). In other words, what some may consider a positive impact may in fact have a negative meaning for others. We need to be careful when we assess the multiple consequences of what we call 'impact'. Scientific practice should not be limited to what is 'applicable' and 'useful' for society, when 'society' might in fact be limited to interest groups that seek to legitimize their intentions through laws and totalizing discourses sold as the 'common good' (Godin \& Doré, 2005; Pitman \& Berman, 2009). Indeed, defining what is good for society always carries some degree of controversy and dispute (Gunn \& Mintrom, 2017).

Thinking about impact within contemporary administration requires that we move beyond managerialism (Clegg, 2014; Klikauer, 2013) which (generally) conceals social problems by presenting itself as 'technical', 'neutral', 
and 'apolitical'. Now, is there anything like social cohesion and society without politics? We cannot confuse the political grammar in Brazil (Nunes, 2010) with the classic concept of politics (Aristóteles, 1997). The Aristotelian notion of politics seeks precisely to promote human happiness and the collective good. If we really want our research to have a positive impact, we need to assess the great social challenges and think about how contemporary administration can contribute to facing them. We need to assess whether the impact of our research serves solely the interests of the few against the common good. Almeida (2012) argues about this aspect: "contemporary is, therefore, someone who can see in the present what is implied, suggested between the lines, hidden or blinded by the seductive, albeit deceiving, clarity of the immediate (Almeida, 2012, p. 80).

\section{CONTEMPORARY ADMINISTRATION IN RAC}

Given what has been presented so far, a special note remains to be made specifically on what $R A C$ hopes to publish. The focus of publications in $R A C$ is to respond to the society's contemporary challenges with new theoretical, methodological and practical possibilities in the realm of the administration of companies, public organizations, or civil society. The various areas of administration can provide different perspectives and contribute to associating contemporary administration with knowledge guided by ethics, diversity, responsibility, governance, sustainability, and other issues that help build better human relationships.

One way to understand how administration can contribute to relevant contemporary issues is by gaining a deep understanding of the UN Sustainable Development Goals. The idea is not to link any work to any specific objective set forth by the UN, but rather to keep in mind what is being considered as challenging and important for global well-being. This should entail a reflection exercise that leads to a self-criticism of the work done. In other words, $R A C$ expects authors to reflect on the following questions: Does my study serve specific interests that do not contribute to or hinder the common good? Does my study promote precarious labor relations, negative environment impacts, disregard for diversity or prioritization of profit over safety, equity and social justice? In making these questions, aims to encourage authors to double check if their manuscripts are oriented to producing and promoting knowledge that helps society (as a whole) to face its dilemmas and challenges.

Our expectation is that continues to be a contemporary scientific journal that fosters the kind of knowledge that can provide the business world, public administration, the third sector or even the civil society with socially responsible practices.

\section{REFERENCES}

Agamben, G. (2009). O que é o contemporâneo? E outros ensaios (Chap. 3, pp. 52-73). Chapecó, SC: Argos, 2009.

Almeida, E. A. A. (2012). Charles Baudelaire: Contemporâneo do passado, do presente e do futuro. Revista Poiésis, 13(20), 73-84. https://doi.org/10.22409/poiesis.1320.73-84

Alvesson, M., \& Willmott, H. (1992). Critical management studies. London: Sage.

Aristóteles. (1997). Política (3 ed.). Brasília: Editora Universidade de Brasília.
Bispo, M. de S. (2021). Ensaiando sobre o velho e falso dilema entre teoria e prática. Teoria e Prática em Administração, 11(2), 174-178. https://doi.org/10.22478/ufpb.2238$\underline{104 X .2021 \mathrm{v} 11 \mathrm{n} 2.59760}$

Bispo, M. de S., \& Davel, E. P. (in press). Editorial: Impacto educacional da pesquisa. Organizaçóes \& Sociedade, in press.

Cabantous, L., \& Gond, J.-P. (2011). Rational decision making as performative praxis: Explaining rationality's éternel retour. Organization Science, 22(3), 573-586. https://doi.org/10.1287/orsc.1100.0534 
Clegg, S. R. (2014). Managerialism: Born in the USA. Academy of Management Review, 39(4), 566-585. https://doi.org/10.5465/amr.2014.0129

Dardot, P., \& Laval, C. (2013). The new way of the world: On neoliberal society. New York: Verso.

Edwards, D. M., \& Meagher, L. R. (2020). A framework to evaluate the impacts of research on policy and practice: A forestry pilot study. Forest Policy and Economics, 114, 101975. https://doi.org/10.1016/j.forpol.2019.101975

Fleming, P., \& Oswick, C. (2014). Educating consent? A conversation with Noam Chomsky on the university and business school education, Organization, 21(4), 568-578. https://doi.org/10.1177/1350508413514748

Ghoshal, S. (2005). Bad management theories are destroying good management practices. Academy of Management Learning and Education, 4(1), 75-91. https://doi.org/10.5465/amle.2005.16132558

Godin, B., \& Doré, C. (2005). Measuring the impacts of science: Beyond the economic dimension. Helsinki, Finland: Helsinki Institute for Science and Technology Studies. Retrieved from www.csiic.ca/PDF/Godin Dore Impacts.pdf

Gunn, A., \& Mintrom, M. (2017). Evaluating the non-academic impact of academic research: Design considerations. Journal of Higher Education Policy and Management, 39(1), 20-30. https://doi.org/10.1080/1360080X.2016.1254429

Klikauer, T. (2013). Managerialism: A critique of an ideology. New York: Palgrave MacMillan.

Lundberg, C. C. (2004). Is there really nothing so practical as a good theory? Business Horizons, 47(5), 7-14. https://doi.org/10.1016/j.bushor.2004.07.003
Nunes, E. de O. (2010). A gramática politica do Brasil: Clientelismo, corporativismo e insulamento burocrático (4 ed.). Rio de Janeiro: Garamond.

Pacheco, E. M. (2010). Dos poros ao sopro: A dimensão estética da experiência. In E. A. Lima, J. L. Ferreira Neto, L. E. Aragon (Orgs.), Subjetividade contemporânea: Desafios teóricos e metodológicos (Chap. 6, pp. 85-94). Curitiba: Editora CRV.

Pio, E, \& Waddock, S. (2021). Invoking indigenous wisdom for management learning. Management Learning, 52(3), 328346. https://doi.org/10.1177/1350507620963956

Pitman, T., \& Berman, J. E. (2009). Of what benefit and to whom? Linking Australian humanities research with its 'end users'. Journal of Higher Education Policy and Management, 31(4), 315-326. https://doi.org/10.1080/13600800903191955

Rancière, J. (2005). A partilha do sensivel: Estética e política. São Paulo: Editora 34.

Rhodes, C., \& Fleming, P. (2020). Forget political corporate social responsibility. Organization, 27(6), 943-951. https://doi. org/10.1177/1350508420928526

Sandes-Guimarães, L. V., \& Hourneaux, F., Junior. (2020). Research impact - what is it, after all? Editorial impact series part 1. RAUSP Management Journal, 55(3), 283-287. https://doi. org/10.1108/RAUSP-07-2020-202

Van de Ven, A. H. (1989). Nothing is quite so practical as a good theory. Academy of Management Review, 14(4), 486-489. https://doi.org/10.5465/amr.1989.4308370

Zanoni, P., Contu, A., Healy, S., \& Mir, R. (2017). Post-capitalistic politics in the making: The imaginary and praxis of alternative economies. Organization, 24(5), 575-588. https://doi.org/10.1177/1350508417713219 


\section{Authorship}

\section{Marcelo de Souza Bispo*}

Universidade Federal da Paraíba, Programa de Pós-Graduação em Administração.

Campus I, Lot. Cidade Universitaria, 58051-900, João Pessoa, PB, Brazil.

E-mail address: rac-eic@anpad.org.br

(D) https://orcid.org/0000-0002-5817-8907

* Corresponding Author

\section{Conflict of Interest}

The author have stated that there is no conflict of interest.

\section{Copyrights}

RAC owns the copyright to this content.

\section{Plagiarism Check}

The RAC maintains the practice of submitting all documents approved for publication to the plagiarism check, using specific tools, e.g.: iThenticate.

\section{SCIENTIFIC EDITORIAL BOARD AND EDITORIAL TEAM FOR THIS ISSUE:}

\section{Editorial Council}

Anielson Barbosa da Silva (UFPB, João Pessoa, PB, Brazil) Antonio Carlos Gastaud Maçada (UFRGS, Porto Alegre, RS, Brazil) Ely Laureano Paiva (FGV, São Paulo, SP, Brazil)

Rogério Hermida Quintella (NPGA/UFBA, Salvador, BA, Brazil) Valmir Emil Hoffmann (UnB, Brasília, DF, Brazil)

\section{Editor-in-chief}

Marcelo de Souza Bispo (UFPB, João Pessoa, PB, Brazil)

\section{Associate Editors}

Ariston Azevedo (UFRGS, Porto Alegre, RS, Brazil)

Carolina Andion (UDESC, Florianópolis, SC, Brazil)

Denize Grzybovski (UPF, Passo Fundo, RS, Brazil)

Eduardo da Silva Flores (FEA/USP, São Paulo, SP, Brazil)

Elisa Yoshie Ichikawa (UEM, Maringá, PR, Brazil)

Emílio José M. Arruda Filho (UNAMA, Belém, PA, Brazil)

Fernando Luiz Emerenciano Viana (Unifor, Fortaleza, CE, Brazil)

Gustavo da Silva Motta (UFF, Niterói, RJ, Brazil)

Henrique Castro Martins (IAG/PUC-Rio, Rio de Janeiro, RJ, Brazil)

Keysa Manuela Cunha de Mascena (Unifor, Fortaleza, CE, Brazil)

Ludmila de Vasconcelos Machado Guimarães (CEFET-MG, Belo

Horizonte, MG, Brazil)

Natália Rese (UFPR, Curitiba, PR, Brazil)

Orleans Silva Martins (UFPB, João Pessoa, PB, Brazil)
Pablo Isla Madariaga (Universidad Técnica Federico Santa María, Chile)

Paula Castro Pires de Souza Chimenti (UFRJ/Coppead, Rio de Janeiro, Brazil)

Rafael Chiuzi (University of Toronto Mississauga, Mississauga, ON, Canada)

Sidnei Vieira Marinho (Univali, São José, SC, Brazil)

\section{Scientific Editorial Board}

André Luiz Maranhão de Souza-Leão (UFPE, Recife, CE, Brazil)

Aureliano Angel Bressan (CEPEAD/UFMG, Belo Horizonte, MG, Brazil)

Bryan Husted (York University, Canada)

Carlos M. Rodriguez (Delaware State University, USA)

Cristiana Cerqueira Leal (Universidade do Minho, Portugal)

Diógenes de Souza Bido (Mackenzie, São Paulo, SP, Brazil)

Erica Piros Kovacs (Kelley School of Business/Indiana University, USA)

Elin Merethe Oftedal (University of Stavanger, Norway)

Fábio Frezatti (FEA/USP, São Paulo, SP, Brazil)

Felipe Monteiro (INSEAD Business School, USA)

Howard J. Rush (University of Brighton, United Kingdom)

James Robert Moon Junior (Georgia Institute of Technology, USA)

John L. Campbell (University of Georgia, USA)

José Antônio Puppim de Oliveira (United Nations University, Yokohama, Japan)

Julián Cárdenas (Freie Universität, Berlin, Germany)

Lucas A. B. de Campos Barros (FEA/USP, São Paulo, SP, Brazil)

Luciano Rossoni (UniGranRio, Rio de Janeiro, RJ, Brazil)

M. Philippe Protin (Université Grenoble Alpes, France)

Paulo Estevão Cruvinel (Embrapa Instrumentação, São Carlos, SP, Brazil)

Rodrigo Bandeira de Mello (Merrimack College, USA)

Rodrigo Verdi (MIT Massachusetts Institute of Technology, Cambridge, USA)

Valter Afonso Vieira (UEM, Maringá, PR, Brazil)

Wagner A. Kamakura (Jones Graduate School of Business, Rice University, Houston, USA)

\section{Editing}

Typesetting and normalization to APA standards: Kler Godoy (ANPAD, Maringá, Brazil); Simone L. L. Rafael (ANPAD, Maringá, Brazil).

Frequency: Continuous publication.

Circulation: Free open access to the full text.

\section{Indexing, Directories and Rankings}

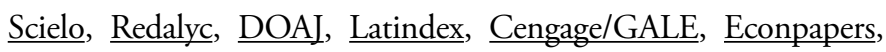

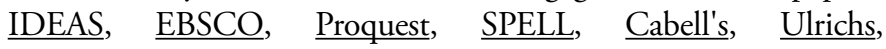
CLASE, Index Copernicus International, Sherpa Romeo, Carhus Plust, Academic Journal Guide (ABS), DIADORIM, $\underline{\text { REDIB }}$ S Sumários.org, ERIHPlus, EZB, OasisBR, IBZ Online, WorldWideScience, Google Scholar, Citefactor.org, MIAR, Capes/Qualis.

RAC is a member of, and subscribes to the principles of the Committee on Publication Ethics (COPE) for scholarly publication 